\title{
Nutritional supplement for indigenous intestinal microflora: manufacturing, quality and effectiveness evaluation
}

\author{
Boisjoni Tokhiriyon*, Valery M. Pozdnykovsky, Valentina Lapina, and Lyudmila \\ Donskova \\ Ural State University of Economics, 620144, Ekaterinburg, Russia
}

\begin{abstract}
The pharmaceutical composition of a nutritional supplement, which has a profound effect on the maintenance and development of the indigenous intestinal microflora, has been scientifically proven. The nutritional supplement is obtained by combining the encapsulation technology with the pellet technology to ensure that the pharmaceutical composition remains intact and the product appeals to consumers. The combination of encapsulation and pellet technology is highly beneficial to the manufacturing process as the delivery of the ingredients, which are very different in absorption and penetration rates, is improved, controlled and becomes very site-specific, while at the same time offering even distribution. The quality of the nutritional supplement has been proven and the product complies with the compulsory sanitary-hygienic and sanitarytoxicological regulations for dietary supplements. Clinical trials for the new nutritional supplement were performed to ensure the safety and the effectiveness of the product. Sixty volunteers aged from 33 to 72 were involved in the clinical trials. All of the volunteers were diagnosed with different intestinal microbiota disorders, among them a decreased number of microbial symbionts (bifidobacteria, lactobacilli, Escherichia coli (Lac + ), the presence of Klebsiella pnenmoniae and opportunistic pathogens like Candida alticans. Patients with intestinal microbiota disorders were prescribed to take 1 capsule of the nutritional supplement twice a day for a period of 30 days together with other medicine prescribed to improve the biocenosis. Having taken part in the clinical trials, nearly $90 \%$ of patients, who had previously experienced such symptoms as bloating, gas, different abdominal pains, cramping, diarrhoea and constipation, demonstrated microbiota restoration, along with the overall health improvement. Considering the findings of the clinical trials, it should be noted that the use of 'Panbiom' nutritional supplement can play an important role in keeping the immune system healthy, with short chain fatty acids becoming the main focus of attention. Short chain fatty acids are the key to stimulating the immune response, as they support the regulatory $\mathrm{T}$ cells, prevent pathological changes and lessen the symptoms. The nutritional supplement composition and the manufacturing process were developed and tested at the scientific research-to-production facilities of Art-Life Scientific Production Association in Tomsk. All the mandatory
\end{abstract}

*Corresponding author: tohiriyoni@gmail.ru 
documentation was obtained and fully complies with the requirements for nutritional supplements.

\section{Introduction}

Although very diverse, many contemporary diets often include a great number of refined food products, which, due to being highly processed to meet the strict storage requirements, lose most of their original nutritional value. This means that after being processed, refined foods contain very small amount of essential macro- and micronutrients per 1,000 kcal, thus, they lack vitamins, minerals, and other biologically active food components. Prolonged deficiencies in these vital nutrients impair our immunity systems and undermine our capability to resist diseases. Nutrient poor diets can affect our health and worsen the quality of life. When the amount of food consumed is increased, the calorie content of the diet grows, which, in turn, leads to overweight and obesity and causes different diseases of civilization like cardiovascular and oncological diseases, etc. [2,5-17].

Therefore, we can assume that achieving a balanced diet that contains all necessary nutrients in certain quantities and proportions and offers the energy value of 2,500-3,000 $\mathrm{kcal}$, while choosing from the products available, is becoming less and less feasible, $[1,3,4]$.

A solution offered by contemporary nutrition scientists includes adding specialised foods, like fortified foods and nutritional supplements with various functional properties, in order to improve the structure of human nutrition and prevent certain disorders. On the one hand, food ingredients of plant, animal, and mineral origin and their combinations have been successfully employed in folk recipes for years and contributed to improved health, on the other hand, modern medicine has carried extensive research and has turned decisively towards disease prevention. A careful combination is needed to ensure suitable diets for human health. It should be noted that nutritional supplements are very different from usual consumer food products as their composition is carefully tailored to address the nutritional needs of certain sub-groups of the populations. The composition of a nutritional supplement can be altered to either include particular ingredients, like vitamins and minerals or their combinations, or remove them from the formula. The nutritional supplements are meant to improve diets and add health benefits and, therefore, come in great variety. There are nutritional supplements for disease prevention, weight control, children, senior people, sportsmen, etc (figure 1)

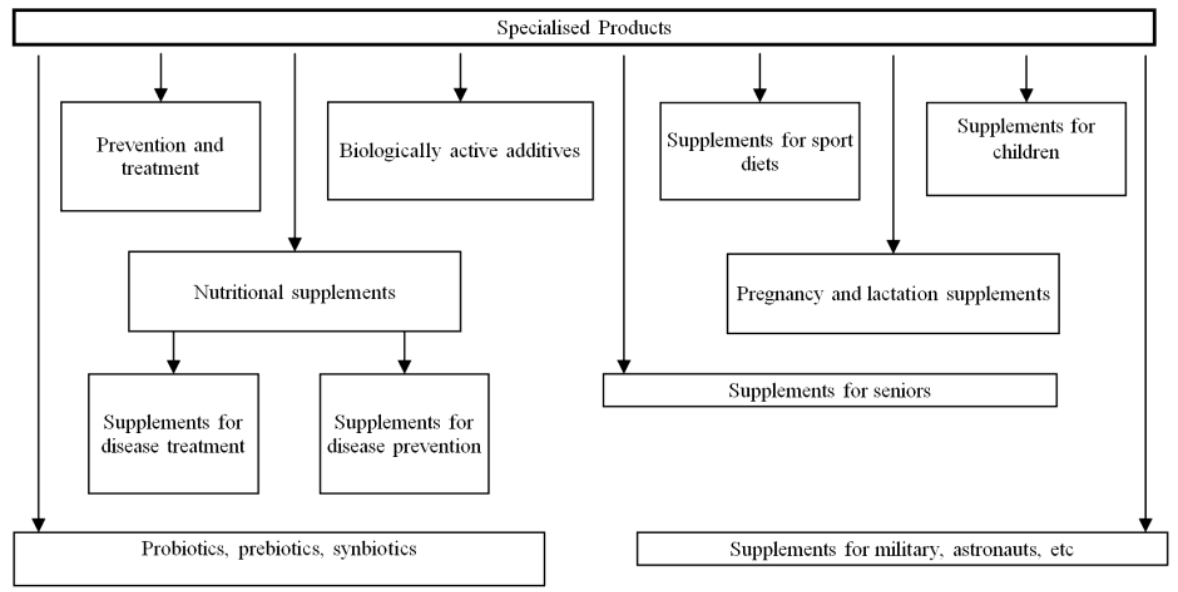

Fig. 1. Specialised Products 
The constantly expanding range of specialised products requires the development and application of scientific principles and techniques in order to improve manufacturing processes and produce safe and effective nutritional supplements to support wellness and help manage certain health conditions.

\section{The purpose of the study}

The purpose of the present study is to assess the quality, effectiveness and functional properties of a new nutritional supplement that was developed to help maintain indigenous intestinal microflora.

\section{Materials and methods}

Live microencapsulated forms of probiotics (bifidobacteria and lactobacilli), prebiotics and samples of 'Panbiom' nutritional supplement that make up the biotechnological treatment plan for indigenous intestinal microflora were studied. Complex testing for quality and safety of nutritional supplement, its effectiveness and purity of ingredients, testing of compliance with the requirements of regulations for specialized products were carried out.

\section{Results and discussion}

The composition of an encapsulated form of 'Panbiom' nutritional supplement, that contains components with synergistic properties and was used in biotechnological treatment plan for indigenous intestinal microflora, is presented in Table 1.

Table 1. The composition of an encapsulated form of 'Panbiom' nutritional supplement

\begin{tabular}{|c|c|c|c|}
\hline Nutritional supplement components & $\begin{array}{c}\text { Amount of } \\
\text { ingredient, } \\
\text { mg / } 1 \text { capsule }\end{array}$ & $\begin{array}{l}\text { Nutritional supplement } \\
\text { components }\end{array}$ & $\begin{array}{c}\text { Amount of } \\
\text { ingredient, } \\
\text { mg / } 1 \\
\text { capsule }\end{array}$ \\
\hline $\begin{array}{l}\text { 'Panbiom' BB-Bf series Biomass } \\
\text { bacteria selective dry } \\
\text { Bifidobacterium bifidum }\end{array}$ & 60 & $\begin{array}{l}\text { 'Panbiom' Biomass } \\
\text { bacteria selective dry } \\
\text { Bifidobacterium breve }\end{array}$ & 30 \\
\hline $\begin{array}{l}\text { 'Panbiom' LB-Cs series Biomass } \\
\text { bacteria selective dry } \\
\text { Lactobacillus casei }\end{array}$ & 60 & $\begin{array}{l}\text { Inulin Fibrulin Instant } \\
\text { Inulin }\end{array}$ & 14 \\
\hline $\begin{array}{l}\text { Biomass bacteria selective dry } \\
\text { Bifidobacterium infantis }\end{array}$ & 50 & $\begin{array}{l}\beta \text {-glucan, 75\% } \\
\beta \text {-glucan }\end{array}$ & $\begin{array}{l}20 \\
15\end{array}$ \\
\hline $\begin{array}{l}\text { LB-Rm Biomass bacteria selective dry } \\
\text { Lactobacillus rhamnosus }\end{array}$ & 50 & Fibrigham B & 5 \\
\hline $\begin{array}{l}\text { LB-Ac Biomass bacteria selective dry } \\
\text { Lactobacillus acidophilus }\end{array}$ & 50 & Lactulose semiproduct & 5 \\
\hline $\begin{array}{l}\text { ‘Panbiom’ BB-Ln Biomass bacteria } \\
\text { selective dry } \\
\text { Bifidobacterium Longum }\end{array}$ & 30 & \multirow{2}{*}{$\begin{array}{l}\text { Ultralizate peptide } \\
\text { PR- Frd Propionibacterium } \\
\text { freudenreichii }\end{array}$} & \multirow[t]{2}{*}{3} \\
\hline $\begin{array}{l}\text { Ultralizate peptide } \\
\text { PR-Propionibacterium arabinosum }\end{array}$ & 3 & & \\
\hline $\begin{array}{l}\text { Inactive ingredients: talc (anti-caking } \\
\text { neosyl GP, pyridoxine hydrochloride, t }\end{array}$ & & $\begin{array}{l}\text { g agent), } \\
\text { sule }\end{array}$ & 96 \\
\hline
\end{tabular}

Considering the scientifically formulated blend of 'Panbiom' nutritional supplement, the use of prebiotics should be emphasised as they represent dietary fiber and are important 
for healthy digestive system. Thorough evaluation of 'Panbiom' nutritional supplement composition demonstrated the following benefits (Figure 2)

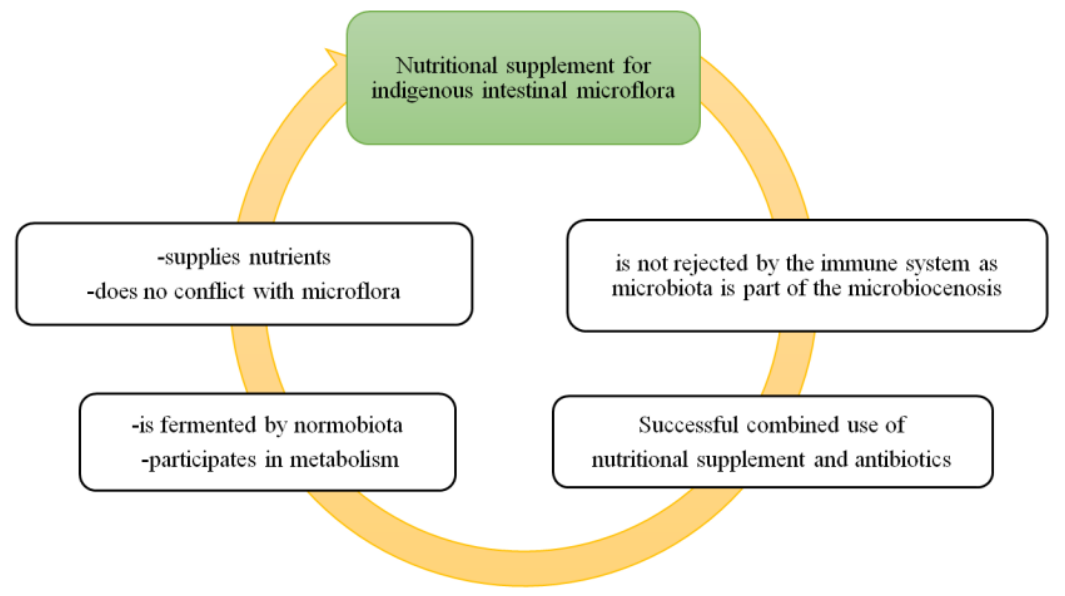

Fig. 2. 'Panbiom' nutritional supplement benefits

The manufacturing process of the nutritional supplement is carried out in accordance with the following production stages (Figure 3).

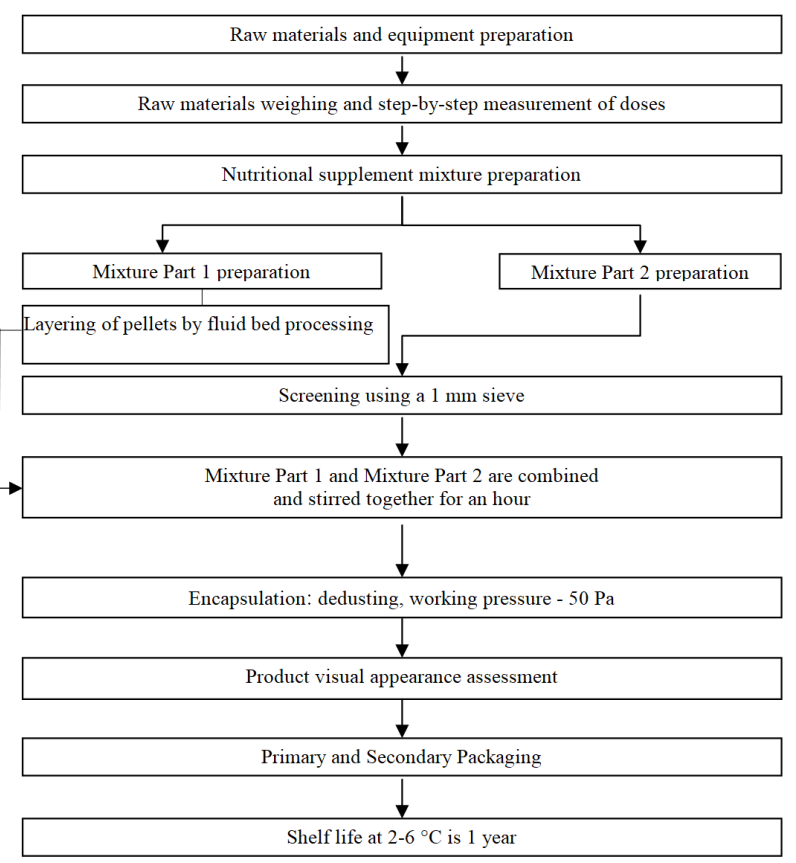

Fig. 3. The manufacturing process of 'Panbiom' nutritional supplement

The layer-by-layer coating of core nutritional supplement ingredients on a spherical solid carrier, separated from each other by a special enteric coating, ensures controlled delivery, controls absorption and enhances bioavailability. The nutritional supplement was stored under $60 \%$ relative humidity and at $2-6^{\circ} \mathrm{C}$ for fifteen months to be again checked for quality, shelf life and stability. 
Having analysed the results obtained, the following sanitary safety indicators (microbiological and toxicological (Table 2)) were used to confirm the shelf life of 1 year stored under the abovementioned conditions. The nutritional supplement is still safe to use 3 months past expiry date and with the content of bifidobacteria and lactobacilli - not less than 5,000,000,000 CFU/g.

Table 2. 'Panbiom' sanitary safety indicators

\begin{tabular}{|c|c|c|c|}
\hline \multicolumn{2}{|l|}{ Indicator } & $\begin{array}{l}\text { Acceptable level in } \\
\text { compliance with TC } \\
021 / 2011\end{array}$ & Actual content \\
\hline \multicolumn{2}{|c|}{ Yeast, CFU/g, no more } & 100 & Less than 10 \\
\hline \multicolumn{2}{|c|}{ Mould, CFU/g, no more } & 100 & Less than 10 \\
\hline \multicolumn{4}{|c|}{ Product weight, g, not allowed } \\
\hline \multicolumn{2}{|l|}{$-E . \operatorname{coli}$} & 1.0 & Not found \\
\hline \multicolumn{2}{|c|}{ - Staphylococcus aureus } & 2.0 & Not found \\
\hline \multicolumn{2}{|c|}{ - Pathogenic, salmonella included } & 10.0 & Not found \\
\hline \multicolumn{2}{|c|}{ - Coliforms } & 0.1 & Not found \\
\hline \multicolumn{4}{|c|}{ Sanitary safety indicators } \\
\hline \multirow[t]{4}{*}{ Toxic elements } & Lead & 0.1 & 0.62 \\
\hline & Arsenic & 0.05 & 0.04 \\
\hline & Cadmium & 0.03 & less than 0.01 \\
\hline & Mercury & 0.005 & less than 0.001 \\
\hline \multirow[t]{4}{*}{ Pesticides } & $\mathrm{HCCH}$ (isomers) & 0.05 & less than 0.005 \\
\hline & DDT and metabolites & 0.05 & less than 0.05 \\
\hline & Heptachlor & not allowed $(<0,002)$ & less than 0.002 \\
\hline & Aldrin & not allowed $(<0,002)$ & less than 0.002 \\
\hline
\end{tabular}

Clinical trials involved 60 volunteers aged from 33 to 72 and diagnosed with different intestinal microbiota disorders, among them a decreased number of microbial symbionts (bifidobacteria, lactobacilli, Escherichia coli ( $\mathrm{Lac}+$ ), the presence of Klebsiella pnenmoniae and opportunistic pathogens like Candida alticans. The volunteers were chosen upon careful examination conducted by the specialists of the accredited medical institution. The volunteers were prescribed traditional treatment for intestinal biocenosis together with 'Panbiom' nutritional supplement. The supplement was prescribed to be taken one capsule twice a day (30 minutes before breakfast and before bed). For therapeutic benefits the supplement had to be taken for 30 days.

By the end of the dietary therapy period, nearly $90 \%$ of patients, who had previously complained about bloating, different abdominal pains, cramping, diarrhoea and constipation, demonstrated microbiota restoration and the overall health improvement.

The results obtained during the clinical trials confirm the significant impact of 'Panbiom' nutritional supplement in keeping the immune system healthy with the help of 
short chain fatty acids. Pathological changes are prevented and the symptoms of intestinal microbiota disorders are lessened due to regulatory $\mathrm{T}$ cells activity.

The probiotics that are used in the nutritional supplement help maintain a healthy balance by interacting with the cells and microbes of the intestine and stimulate an adaptive immune response to ensure overall health. A significant contribution to the study of microflora and the immune system was made by Ilya Ilyich Mechnikov, the remarkable Russian scientist, who was awarded (together with Paul Ehrlich) the Nobel Prize in 1908 to recognise their research on immunity. Their theory explained phagocytosis when the phagocyte kills and digests the pathogen as well as the principles of maintaining harmony. In his book, 'Studies of optimism', Mechnikov explains that the main reason for the reduction of human longevity is the build-up of toxic metabolic by-products, while hostfriendly bacteria help maintain overall health.

Host-friendly bacteria like probiotics perform a range of functions:

- participate in the mucus and protein build-up on the intestinal walls and, thus, protect against invading bacteria and other pathogens,

- stimulates the intestinal mucosa to secrete def enzymes, the antimicrobial substances that protect against invading fungi and viruses.

The performance of particular functions depends on probiotic strains and there is no one-size-fits-all approach, thus, to experience the health benefits offered by probiotics, we have to find the right nutritional supplement.

\section{Conclusion}

Building upon the results obtained during the clinical trials and having met all the necessary regulatory requirements, the conclusion was drawn that the studied nutritional supplement can be included in biotechnological treatment plan for indigenous intestinal microflora, recommended for intestinal microbiota disorders prevention, and used for developing immunity. The recommended daily intake is 1 capsule taken with a meal. All the necessary documents and certificates for the nutritional supplement have been obtained.

\section{References}

1. Yu. S. Boytsova, International journal of humanitarian and natural sciences, 42 (3-1), $51(2020)$

2. A.V. Pogozheva, Consilium Medicum, 18(12), 55 (2016)

3. E.A. Pyreva, A.I. Safronova, Questions of nutrition, 88(6), 5 ( 2019)

4. O.G. Stukalo, Yu.A. Tekuteva, Bulletin of the Voronezh State University of Engineering Technologies, 4 (74), 350 (2017)

5. S. Yu. Tereshchenko, E.V. Kasparov, E.I. Prakhin, E.N. Anisimova, M.V. Shu-bin, N.N. Gorbachev, Questions of children's dietetics, 15 (5), 15 (2017)

6. B. Tokhiriyon, A.A. Vekovtsev, O. N. Bulashko et al., Bulletin of SUSU. Food and Biotechnology Series, 8(2), 65 (2020)

7. A.A. Utebaeva, M.A. Burmasova, M.A. Sysoeva, Applied Chemistry and Biotechnology, 4 (19), 100 (2016)

8. B. Tokhiriyon, V.M. Poznyakovsky, N.M. Beliaev, International Journal of Pharmaceutical Research \& Allied Sciences, 8 (1), 115 (2019)

9. B. Tokhiriyon, V.M. Poznyakovsky, S. Andrievskikh, Carpathian journal of food science and technology, 12 (1), 52 (2020) 
10. N. Lund, M.L. Westergaard, M. Barloese et al., Cephalalgia, 34(10), 833 (2014)

11. D.C. Murador, N. Vannuchi, et al., Current opinion in food science, 26, 25 (2019)

12. K.K. Witte, R. Byrom, JACC Heart Fai, 2, 318 (2014)

13. F. Di Pierro, A. Bertuccioli, R. Giuberti, et al., Minerva gastroenterologica e dietologica, 66, 29 (2020)

14. L. Krupytska, L. Kaprelyants, L. Trufkati, et al., Journal of food science and technology, 12, 13 (2018)

15. P. Markowiak, K. Śliżewska, Nutrients, 9 (2017)

16. G.C. Pistol, D.E. Marin, M.C. Rotar, et al., Journal of functional foods, 66, 1 (2020)

17. RAND The Global Technology Revolution 2020, In-depth Analyses (Bio/Nano/ Materials/Information Trends, Drivers, Barriers, and Social Implications). Santa Monica, CA: RAND Corporation (2006) 